\title{
Daphnia as a model organism in limnology and aquatic biology: introductory remarks
}

\author{
Jaromir SEDA* and Adam PETRUSEK ${ }^{1)}$ \\ Biology Centre, Academy of Sciences of the Czech Republic, CZ-37005 Ceske Budejovice, Czech Republic \\ ${ }^{1)}$ Charles University in Prague, Department of Ecology, Faculty of Science, Viničná 7, CZ-12844 Prague, Czech Republic \\ *e-mail corresponding author: seda@hbu.cas.cz
}

\section{ABSTRACT}

Cladocerans of the genus Daphnia are keystone pelagic filter feeders in many temperate ponds and lakes. They have also become popular model organisms in various biological disciplines, from aquatic ecology to biomedical sciences. The crucial features that make these organisms excellent experimental models are their cyclical parthenogenetic life cycle together with easy culturing and handling. Thanks to these characteristics, the number of publications dealing with Daphnia is rapidly growing. The special insert to the Journal of Limnology on Daphnia biology contains contributions that deal directly or indirectly with the reproduction and development of these water fleas, in relation to various ecological factors. These include predator-prey interactions and their impact on morphology, population dynamics, or senescence-related traits, growth of daphnids on a diet consisting of invasively spreading cyanobacteria, and also the impact of extreme floods on a Daphnia population (and particularly on its dormant ephippial egg bank) in a reservoir. Here, we discuss these presented works, and point out the potential lines of research that may improve the generalisation of their findings.

Key words: senescence, cyanobacteria, inducible defences, flood impact, egg banks, fish predation

Progress in biology is to a large extent linked with the study of model organisms, which give us insights into various aspects of life on Earth. A good model organism combines many features, starting with easy cultivation and handling, a reasonable size, and a short generation time, but undeniably crucial feature of any good model is the possibility to ask relevant questions and generalise the findings. Some model organisms represent widespread and economically important taxa, others have been chosen because of their biological features.

Probably the most famous invertebrate model is the fruitfly Drosophila, which for many decades has advanced our knowledge on animal genetics and development, and has become indispensable in a wide range of biological disciplines. The range of model organisms in biological research is nevertheless much wider, and encompasses a number of animal species from various taxonomic groups. Recently, the water flea Daphnia joined the "distinguished" ranks of model species for biomedical research acknowledged by the US National Institutes of Health (see http://www.nih.gov/science/ models), becoming only the second arthropod in the list after Drosophila. For a long time, Daphnia has been recognised as a keystone species in the food webs of many continental water bodies, and has served as an important model for ecological, evolutionary or ecotoxicological research (to name just a few prominent fields). The factors that make daphnids particularly popular for experimental work include all those listed above for a suitable model; these are complemented by cyclical parthenogenetic life cycle that includes diapausing stages. Simple culturing of genetically distinct clones thus allows experiments disentangling the effects of environmental and genetic factors. The popularity of these small planktonic crustaceans is likely to be further boosted by the recent publication of a Daphnia genome (Colbourne et al. 2011), the first crustacean genome to be completed. It can be expected that the involvement of water fleas in other biological disciplines will further boost the number of studies and range of topics focused on this group. A rough comparison of the number of published papers indexed by the ISI Web of Science dealing directly or indirectly with various model organisms (Fig. 1) shows that water fleas are not a match for long-established laboratory models such as fruit flies, the round worm Caenorhabditis elegans, or the African clawed frog Xenopus (not mentioning the most common laboratory animals, mice and rats, with over 100,000 hits in the last five years, which were not included in the figure). However, it is likely that Daphnia are by far the best known aquatic invertebrates.

With the increasing number of scientific publications on Daphnia, our knowledge is expanding in various fields, including its ecology, evolution, diversity, bio- and phylogeography, roles in host-parasite and predator-prey interactions, and response to natural and anthropogenic stressors such as toxic compounds, to name just a few. On the other hand, it becomes increasingly difficult to critically analyse and generalise the bits of information contained in the published papers. Therefore, attempts to summarise the present state of at 


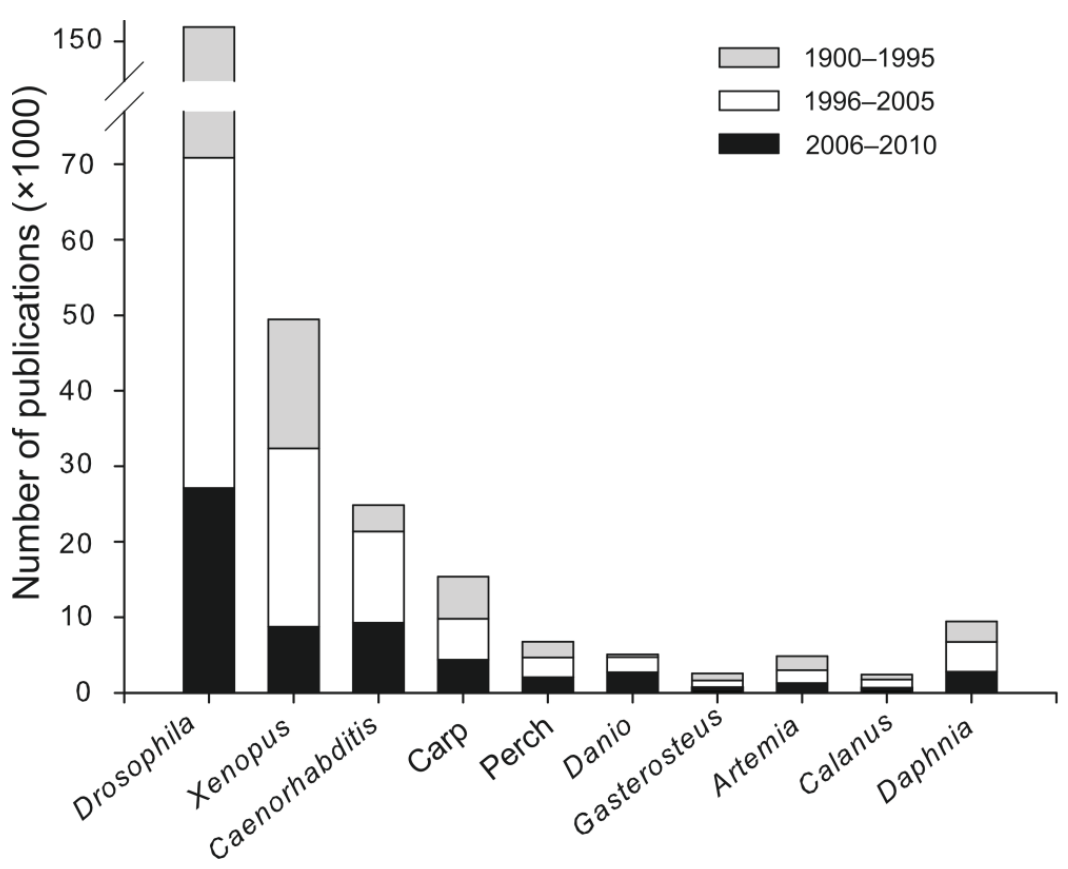

Fig. 1. The number of publications on selected animal taxa indexed in the ISI Web of Science in May 2011. Apart from established model species, several other important fish and crustacean species are included. The most common laboratory animals, mice and rats, are not listed. The search criterion was the Latin name of the genus (with the exception of perch and carp, for which English names were used to increase the hit likelihood). Given the limited coverage of the database and its changes throughout time, the values do not reflect temporal changes but allow a rough comparison among taxa. Note that most search words retrieve publications on multiple species, and that the search results also include some papers that do not deal with the respective taxon directly (but it is mentioned in the abstract or included in the KeyWords Plus feature of the database).

least some wider field are particularly welcome. In this context, we would like to highlight a recent monograph focusing on the ecology and evolution of Daphnia (Lampert 2011). Along with the taxonomic compendium by Benzie (2005), it has become another prominent "Daphnia book" within a relatively short time that should certainly find its place on the bookshelves of limnologists and aquatic ecologists. On many such shelves, it will join a "citation classic" in the field, the monograph edited by Peters \& de Bernardi (1987) shortly entitled "Daphnia". This was published as a special issue of the journal well-known among limnologists and aquatic biologists, Memorie dell'Istituto Italiano di Idrobiologia, of which the Journal of Limnology is a direct descendant.

The contributions presented in this special insert of the journal do not have such ambitions, but do advance our knowledge on the reproduction, development and ecology of this important taxon. In these introductory remarks, we will discuss these works and attempt to point out their strengths and limitations. In particular, we would like to highlight the difficulty of generalising published findings dealing with various aspects of Daphnia life, and point out some potentially fruitful future lines of research.

Pietrzak (2011, this issue) studied the senescence of daphnids and the evolutionary patterning of different aging strategies. The initial hypothesis is simple, and should be relevant for Daphnia from different environments: "the evolutionary theory of senescence predicts that under high extrinsic mortality, when few individuals survive until older ages, there is strong selection for high investments in early fitness, which together with loosened selection for investments in late life fitness results in faster aging" (Williams 1957). The author compared life tables of Daphnia magna clones from two localities with contrasting environments, including predation regimes: the North German lake Grosser Binnensee (with fish) and from a fishless city pond in Warsaw. The assumption underlying the choice of localities (apart from availability of clones, which could certainly play a role) was that fish predation causes much earlier mortality of Daphnia in the lake with fish than in the fishless pond. According to predictions of the theory, this might result in microevolutionary changes in traits related to senescence. Unfortunately, the conclusions of the study are limited by the low number of clones tested (two from each locality). Strong interclonal variation was observed by Pietrzak, but only lifespan differed consistently between the lake and pond clones.

The study was conducted on Daphnia magna, a prominent model species used by many European research groups. The choice of D. magna over other species has many advantages, including large size (for a Daphnia species) and easy handling and culturing under laboratory conditions. In particular, D. magna does not suffer from attachment to the water surface, a fate that 
increases the handling mortality of many small Daphnia species. For research into senescence, however, one might consider choosing other Daphnia species, the populations of which might show stronger fish predation effects on senescence-related traits.

D. magna is known from a wide range of habitats, from temporary fishless pools to large permanent lakes (both natural and artificial) that are moderately stocked with fish. It has been shown that this species responds to variation in fish predation intensity by fast microevolutionary changes (Cousyn et al. 2001). High densities of planktivorous fish are nevertheless limiting for the species. Several other European Daphnia occur in habitats ranging from no to high fish predation pressures. Among these, some members of the D. longispina complex might be particularly suitable for testing how environmental conditions affect senescense. Populations of D. longispina (sensu Petrusek et al. 2008) occur from small fishless pools (including high-altitude alpine ponds) to lakes with various extent of fish predation. Adaptations to different environmental conditions resulted in different forms of the species to be described under several names (of which at least $D$. rosea, $D$. hyalina, and $D$. zschokkei persisted in the literature in the late $20^{\text {th }}$ Century); however, these do not seem to show any genetic differentiation that would substantiate such taxonomic splitting (Petrusek et al. 2008; Thielsch et al. 2009).

Given the variation of phenotypes and life-history characteristics among $D$. longispina populations, it is likely that senescence-related traits may differ as well. Furthermore, aging in Daphnia might be affected not only by extrinsic mortality due to predation, but also by the food levels, i.e., the trophic state of the locality. Thus, a contrast between $D$. "hyalina" from lakes with planktivorous fish, and long-established populations from fishless oligotrophic alpine lakes and ponds (with the extreme being the melanized D. "zschokkei" from the Alps) could be much stronger than between $D$. magna from a lake with moderate fish stock and a relatively recently colonised city pond. Similarly, $D$. galeata is an extremely plastic species that occurs in almost all types of permanent water bodies throughout Europe (Kořínek 1987; Seda \& Duncan 1994; Gliwicz 2003). The size structures of its populations are strongly correlated with fish predation intensity, and the species is able to persist in localities even when the fish densities change by two orders of magnitude (Černý \& Bytel 1991; Seda \& Kubečka 1997).

Clones of Daphnia magna from Grosser Binnensee Lake have often been used in experimental studies. There are well over 30 publications analysing local $D$. magna populations from various points of view. These often refer to the lake as a locality with strong fish predation (e.g., Lampert 1991; Loose \& Dawidowicz 1994). While this might be true from the D. magna point of view, the persistence of such a large-bodied
Daphnia species itself reveals that the fish stock levels in the lake are moderate. D. galeata coexists in Grosser Binnensee with D. magna (Jürgens \& Stolpe 1995), and would undoubtedly persist in the locality even if the predation pressure increased and D. magna disappeared. Given the ability of several members of the D. longispina complex to withstand a very wide range of predation regimes, it would be interesting to conduct experiments similar to those performed by Pietrzak (2011, this issue) with clones of D. galeata or D. longispina coming from localities with a wide gradient of fish predation. To test for general patterns rather than specific local adaptations, it would be also desirable to include clones from multiple localities representing predation regime.

Bednarska et al. (2011, this issue) address the "hot" problem concerning the impact of increasing temperatures in aquatic ecosystems due to climate changes, with a focus on the increased importance of filamentous cyanobacteria in the phytoplankton under such conditions. They studied the influence of the invasively spreading tropical to subtropical cyanobacterium Cylindrospermopsis raciborskii on the keystone planktonic herbivore Daphnia magna under two different temperatures. The authors used a non-toxic strain of Cylindrospermopsis in their experiment. Thus, the expected adverse effect on Daphnia was not through the production of cyanotoxins but rather due to a deficiency of some essential compounds and the morphology of cyanobacterial filaments, which are difficult for daphnids to handle (Gliwicz \& Siedlar 1980; Müller-Navarra 1995). Bednarska et al. suggest that a predicted increase of surface water temperature in the range from $20^{\circ} \mathrm{C}$ to $24^{\circ} \mathrm{C}$ is unlikely to strongly suppress Daphnia through interactions with such cyanobacteria, but may result in microevolutionary changes by influencing clonal selection within Daphnia populations. Such a scenario seems likely given the microevolutionary potential of Daphnia (Hairston et al. 1999). However, the design of the experiment, which focused only on the short-term impact of feeding by cyanobacterial filaments, and used only single-species high- or low-quality diets, limits any generalisation.

The relationship between the nutritional value of one particular cyanobacterial strain and Daphnia feeding in real lakes is very complex. Daphnia obtain various essential compounds from their food that are necessary for successful growth and reproduction. While earlier works stressed the importance of polyunsaturated fatty acids (PUFAs) for nutrition (e.g., Gulati \& DeMott 1997), many recent studies focus on an analysis of sterol content in the food (e.g., Martin-Creuzburg et al. 2008; Martin-Creuzburg \& von Elert 2009). It is nevertheless assumed that the contents of both groups of these essential compounds are positively correlated in seston dominated by cyanobacteria (von Elert et al. 2003). 
While cyanobacteria are undoubtedly suboptimal food for daphnids, their nutritional value may vary substantially. For example, cyanobacterial cells usually show a deficiency but not complete absence of PUFAs (Ahlgren et al. 1992). C. raciborskii in particular is able to increase PUFA content substantially (Zsiros et al. 2000; Guschina \& Harwood 2006). This is considered to be a physiological adaptation of its cells to lower temperatures (Murata 1989); however, this "cold" adaptation was tested for this primarily tropical and subtropical species by decreasing the ambient temperature from 30 ${ }^{\circ} \mathrm{C}$ to $25^{\circ} \mathrm{C}$, a temperature environmentally relevant for strains invading European waters. On the other hand, Reinikainen et al. (2001) showed that cyanobacteriaproduced PUFAs, in contrast to those produced by green algae, may be toxic.

The nutritional quality of $C$. raciborskii in European lakes may thus depend on several factors. It is quite possible that if the particular cyanobacterial strain does not produce the toxic alkaloid cylindrospermopsin (the presence of non-toxic strains of this species seems to be mostly the case in European waters; Neilan et al. 2003), it might not be a particularly bad food source for Daphnia. The main problem with cyanobacterial blooms is usually not the excessive biomass but the production of toxins (Huisman et al. 2005; Lopez-Rodas et al. 2008). Within one lake, toxic and non-toxic strains may coexist (Via-Ordorika et al. 2004; Saker et al. 2005), so the resulting impact on planktonic grazers will certainly depend on the ratio between such strains, and their ratio to other phytoplankton taxa (Lürling 2003). Furthermore, the digestive processes of Daphnia may at least to certain extent adapt to the presence of cyanobacterial toxins (Blom et al. 2006). This can be demonstrated by well-documented microevolutionary changes in the resistance to cyanobacteria of a Daphnia population from Lake Constance (Hairston et al. 1999), in which eutrophication and subsequent re-oligotrophication over four decades resulted in substantial changes in cyanobacterial densities.

Juračka et al. (2011, this issue) deal with Daphnia morphological antipredator adaptations, another topic in which this genus has become a popular model. They provide experimental evidence for the formation of neckteeth in two related European species of the D. curvirostris complex in response to presence of Chaoborus cues. One of the studied species, D. hrbaceki recently described from Central Europe (Juračka et al. 2010), provides a good example of the extent of gaps in our knowledge of Daphnia diversity. This species was discovered in a region where zooplankton research has a long tradition, and it would most likely have continued to escape recognition if it did not form conspicuous "hunchback" phenotypes in response to Chaoborus in the field. It is likely that not only understudied exotic regions but also those seemingly well studied ones still harbour a number of Daphnia cryptic lineages (see Petrusek et al. 2008 or Adamowicz et al. 2009 for further examples).

The existence of neckteeth in some Daphnia species has been well known since the $19^{\text {th }}$ Century (e.g., Matile 1890). However, their relationship to antipredator strategy was shown much later (Krueger \& Dodson 1981), and only relatively recently have other mechanisms associated with neckteeth formation been demonstrated (Laforsch et al. 2004). Juračka et al. (2011, this issue) list 13 Daphnia species from several species complexes that are known to produce these structures, all belonging to $D$. pulex or D. longispina groups. The ability to form neckteeth in response to Chaoborus seems widespread among species of the subgenus Daphnia, including those for which it has not been generally recognised. This led Juračka et al. to suggest that these structures may be of common origin but expressed in some taxa only. Such hypothesis may be testable with rapidly advancing genomic methods (see Tollrian \& Leese 2010).

A loss or gain of the potential to form neckteeth might be apparent not only among species but possibly also among conspecific populations long-adapted to different habitats. Neckteeth-forming is very beneficial in relatively small water bodies where Chaoborus presence is common. However, the loss or weakening of such ability in populations in large lake habitats may not be disadvantageous. A good candidate species, on which such a process may be evaluated, is D. longispina. As discussed above, this taxon shows strong phenotypic adaptations to various habitats that differ, among other factors, in predation pressure. It is likely that pressures exerted by Chaoborus on the one hand, and fish on the other, result in rapid microevolutionary changes of antipredator mechanisms in D. longispina.

Another factor that deserves further attention in studies that evaluate the effect of chemical cues in water is the cue concentration. The results of Juračka et al. (2011, this issue) also confirm that kairomone concentration may have an important effect on the level of prey response. They performed two experiments with different predator densities, and the phenotypic response of Daphnia prey was stronger in the higher-density predator treatment. Even in the lower-density experiment, however, there were over three Chaoborus larvae per litre, a concentration substantially exceeding those typically reported in studies dealing with Chaoborus in the field (e.g., Yan et al. 1985; Wissel et al. 2003; Eckmann 1998). This is not unusual, as experiments on Daphnia reacting to predator kairomones often use relatively high concentrations of the chemical cue. These include works on fish kairomones (e.g., Macháček 1991; Stibor 1992) to which the response of Daphnia is also concentration-dependent (Reede 1995). In the field, however, daphnids also clearly respond to relatively low kairomone concentrations, apparently using other additional cues from the environment. In some species, including 
for example $D$. hrbaceki and D. pulex (Juračka et al. 2011, this issue; Vuorinen et al. 1989; Tollrian 1993), there is a tendency of some clones to at least weakly exhibit these antipredation structures even in the absence of any predator cue.

Interestingly, a recent paper by Hwang et al. (2009) briefly mentions the formation of neckteeth together with helmets in Daphnia (Ctenodaphnia) similoides in the presence of predatory cyclopoid kairomones. Unfortunately, no details are given, so the relationship of morphological changes in this Ctenodaphnia to other known cases of phenotypic plasticity in Daphnia cannot be assessed from the published data. If the structures observed by Hwang et al. (2009) are really equivalent to the neckteeth of other species, it would represent a unique combination of different antipredator structures, and the range of both predators and prey that are involved in neckteeth formation would be substantially extended. In such a case, the existence of neckteeth-like structures in Ctenodaphnia would rather support the hypothesis of their independent origin.

The contribution of Vaníčková et al. (2011, this issue) deals with the very timely topic of extreme climatic events. They studied the impact of strong floods on the pelagic Daphnia, and particularly their ephippial egg banks, in a reservoir. The long-term data on inflow into the studied locality (Vranov Reservoir, Czech Republic) demonstrate well that the occurrence in March 2006 of a 500-year flood (i.e., one with a 0.002 likelihood of occurring in any single year) did not mean, despite popular belief, that a similar one would not repeat for centuries. A flood of similar magnitude affected the same reservoir again within less than three months. This supports climatic models, which predict that in the near future we may expect increased variation in precipitation, both in spatial distribution and intensity, in the northern hemisphere (Mearns et al. 1995; Folland et al. 2002).

The study of Vaníčková et al. revealed what impact the floods had on the sediment and the Daphnia egg banks in the Vranov Reservoir. No layer of newly deposited material, recognisable visually, by loss on ignition, or by the absence of Daphnia ephippia, was observed in the cores sampled multiple times after the flood. Apparently, the sediment (including the ephippia within) had been resuspended by the flood, which may have provided an opportunity for hatching even to dormant eggs that would have been otherwise buried in the sediment below the active egg bank. On the contrary, an extreme flood of similar magnitude, which in 2002 hit another Czech canyon-shaped reservoir Rímov, deposited an unmistakable $c a 5-6 \mathrm{~cm}$ thick layer of allochtonous sediment that is devoid of ephippia, and can be recognised both visually and by its organic content even after several years (Hejzlar et al. 2008; I. Vaníčková, unpubl. data). Apparently, the impact of major floods on the distribution and deposition of sediments in reservoir is variable, and may be strongly site-specific.

The large, limnologically well studied Lake Constance, with a theoretical retention time of 4.5 years, was affected by a major flood in winter 1999 (Johnk et al. 2004). This flood had a strong negative impact on the reed stands in the lake littoral zone (e.g., Schmieder et al. 2002; Ostendorp et al. 2003). It was most likely due to elevated water level, which impacted emergent macrophytes through oxygen deficiency (Koppitz 2004). It is not clear how much allochthonous sediment was brought into the lake by this flood. However, Jankowski \& Straile (2003), who collected sediment cores from Lake Constance in 2000 for ephippia analyses, do not mention the flood at all, which suggests that its impact on the ephippial banks was negligible.

When a major flood impacts a standing water body during the growing season, the zooplankton may be partially or completely flushed out (Threlkeld 1986; Dirnberger \& Threlkeld 1986). Subsequent recovery depends, among other factors, on the length of the period of increased turbidity, and on the impact of turbidity on different taxa (Threlkeld 1986; Kirk 1991; Boenigk \& Novarino 2004; Rellstab \& Spaak 2007). In eutrophic reservoirs, the recovery of crustacean plankton populations may be relatively fast, even within weeks (Vaníčková et al. 2011, this issue; Seda, unpublished data). On the contrary, recovery in oligotrophic lakes may take months (Rellstab et al. 2007). For fish populations, a strong flood during the reproduction period may have even a positive impact (Gido et al. 2000; Kahl et al. 2008), resulting in a strong cohort that survives and influences other trophic levels through the top-down effect over several years.

It is apparent that the impact of floods on lakes may be very complex, including the removal of planktonic organisms, increased turbidity, import or redistribution of sediment and the dormant stages of aquatic organisms, reduction of littoral macrophytes, and the impact on fish population dynamics. Many of these direct effects on some lake biota groups indirectly affect other trophic levels. For zooplankton, including Daphnia populations, recovery after extreme floods nevertheless seems relatively fast, to which in-situ survival, import, as well as emergence from dormant stages may contribute.

The final contribution of this special insert points to the importance of interactions between bottom-up and top-down factors on the Daphnia midsummer decline. The paper by Hülsmann (2011, this issue) supports the view that Daphnia dynamics is strongly linked to the dynamics of young-of-the-year fish (YOY), which are gap-limited in the in their first weeks of life, roughly corresponding to the clear-water phase. The Daphnia population structure during this period is dominated by a single cohort of adults, which continue to grow and to reproduce at a low level. The end of the clear-water fase 
is marked by an alteration of Daphnia generations caused by YOY predation. The critical fish body size for this top-down effect is estimated at $25 \mathrm{~mm}$ (total length), a size allowing feeding on even the largest size classes of lake Daphnia. The critical biomass of YOY is assumed to be $200 \mathrm{mg}$ wet weight $\mathrm{m}^{-3}$. It is worth pointing out that by multiplying the biomass value by the depth of the epilimnion, we get the "magic" value of $20 \mathrm{~kg} \mathrm{ha}^{-1}$, i.e., the critical biomass of YOY in Oneida Lake reported by the pioneering work of Mills \& Forney (1983).

It is unfortunate that Hülsmann (2011, this issue) could not report the biomass and dynamics of YOY in the last year of his three-year study (1999), when the Daphnia midsummer decline did not occur. It would not only complement the data from the preceding years, but it would also allow a direct comparison with previous results of experimental fish stock manipulations in the same locality (Hülsmann \& Mehner 1997). In that study, the authors conclude that even high abundances of YOY may not be fully responsible for the Daphnia decline, and that the contribution of low food supply, i.e., bottom up processes, is important.

Among-year and among-lake variation of YOY is also an important factor that might contribute to Daphnia dynamics. In the eutrophic, relatively shallow Bautzen Reservoir studied by Hülsmann, August YOY abundances extrapolated from the study by Wagner et al. (2004) are around 0.1 ind. $\mathrm{m}^{-3}$. In six reservoirs of the Czech Republic studied by Jůza et al. (2006), these values ranged between 0.06 and 0.001 YOY m$~^{-3}$, i.e., mostly substantially lower. However, among-year variation of August YOY abundance in the deep Rímov Reservoir ranged within the same order of magnitude, from 0.001 to 0.15 ind. $\mathrm{m}^{-3}$ over seven years (Jůza et al. 2009). Despite this substantial variation, there was no correlation of YOY abundance and August size structure of the local Daphnia population, or with the extent of summer Daphnia decline. On the contrary, long-term monitoring of $1^{+}$zooplanktivorous fish in Rímov Reservoir over a 14-year period revealed a close relationship between the Daphnia size structure and the fish stock (Seda \& Kubečka 1997). However, this was mainly due to large changes in the $1^{+}$fish stock during the investigated years $\left(20\right.$ to $\left.650 \mathrm{~kg} \mathrm{ha}^{-1}\right)$. A midsummer Daphnia decline was not recorded even under $550 \mathrm{~kg} \mathrm{ha}^{-1}$ of $1^{+}$ fish (Seda 1989; Seda \& Kubečka 1997). Thus, we may conclude that defining the so-called critical values for Daphnia-fish interactions is problematic, as each individual study is dependent on lake trophy and depth, and also on the fish stock structure and Daphnia species present.

As is usually the case, the above-discussed papers improve our knowledge on certain topics but open a number of unanswered questions, which may stimulate further research in their respective fields. Experimental works, which are almost always grossly simplified in comparison with real-world situations, usually shed light on only one or a few of the many facets of the studied problem, so one should be cautious when interpreting and generalising the results. This issue may be highlighted on the study by Bednarska et al. (2011, this issue), which focused on the short-term impact of Daphnia-cyanobacteria interactions. However, generalising field studies may be just as complicated, especially if they focus on a single locality and/or a unique event as does for example the paper by Vaníčková et al. (2011, this issue) on the impact of 500-year floods in a reservoir.

Despite their limitations, all such studies represent an advance in aquatic ecology and the knowledge of Daphnia biology, and some have the potential to also influence other biological disciplines. Given the potential of Daphnia as a model organism, and the popularity which it is gaining in a wide range of research fields, we may be sure that papers dealing with these water fleas will continue to fill the pages of scientific journals, including the Journal of Limnology.

\section{ACKNOWLEDGEMENTS}

We acknowledge the support by the Academy of Sciences of the Czech Republic (projects 1QS600170504 and AVOZ60170517), the Czech Ministry of Education (MSM0021620828), and the Czech Science Foundation (P506/10/P167). The International Conference on Invertebrate Reproduction and Development, where the authors of the papers presented their work, was in part supported by funding from the European Community's Seventh Framework Programme (FP7/2007-2013) under grant agreement no. 229518.

\section{REFERENCES}

Adamowicz, S.J., A. Petrusek, J.K. Colbourne, P.D.N. Hebert \& J.D.S. Witt. 2009. The scale of divergence: a phylogenetic appraisal of intercontinental allopatric speciation in a passively-dispersed freshwater zooplankton genus. Mol. Phylogenet. Evol., 50: 423-436.

Ahlgren, G., I.B. Gustafsson \& M. Boberg. 1992. Fatty acid content and chemical composition of freshwater microalgae. J. Phycol., 28: 37-50.

Bednarska, A., J. Łoś \& P. Dawidowicz. 2011. Temperaturedependent effect of filamentous cyanobacteria on Daphnia magna life history traits. J. Limnol., 70(2): 353-358.

Benzie, J.A.H. 2005. Cladocera: The genus Daphnia (including Daphniopsis). Kenobi Productions, Gent \& Backhuys Publishers, Leiden: 376 pp.

Blom, J.F., H.I. Baumann, G.A. Codd \& F. Jüttner. 2006. Sensitivity and adaptation of aquatic organisms to oscillapeptin $\mathrm{J}$ and $\left[\mathrm{D}-\mathrm{Asp}^{3}\right.$, (E)-Dhb $\left.{ }^{7}\right]$ microcystin-RR. Arch. Hydrobiol., 167: 547-559.

Boenigk, J. \& G. Novarino. 2004. Effect of food suspended clay on the feeding and growth of bacterivorous flagelates and ciliates. Aquat. Microb. Ecol., 34: 181-192.

Colbourne, J.K., M.E. Pfrender, D. Gilbert, W.K. Thomas, A. Tucker, T.H. Oakley, S. Tokishita, A. Aerts, G.J. Arnold, M.K. Basu, D.J. Bauer, C.E. Cáceres, L. Carmel, C. Casola, J.-H. Choi, J.C. Detter, Q. Dong, S. Dusheyko, B.D. Eads, T. Fröhlich, K.A. Geiler-Samerotte, D. Ger- 
lach, P. Hatcher, S. Jogdeo, J. Krijgsveld, E.V. Kriventseva, D. Kültz, C. Laforsch, E. Lindquist, J. Lopez, J.R. Manak, J. Muller, J. Pangilinan, R.P. Patwardhan, S. Pitluck, E.J. Pritham, A. Rechtsteiner, M. Rho, I.B. Rogozin, O. Sakarya, A. Salamov, S. Schaack, H. Shapiro, Y. Shiga, C. Skalitzky, Z. Smith, A. Souvorov, W. Sung, Z. Tang, D. Tsuchiya, H. Tu, H. Vos, M. Wang, Y.I. Wolf, H. Yamagata, T. Yamada, Y. Ye, J.R. Shaw, J. Andrews, T.J. Crease, H. Tang, S.M. Lucas, H.M. Robertson, P. Bork, E.V. Koonin, E.M. Zdobnov, I.V. Grigoriev, M. Lynch \& J.L. Boore. 2011. The ecoresponsive genome of Daphnia pulex. Science, 331: 555-561.

Cousyn, C., L. De Meester, J.K. Colbourne, L. Brendonck, D. Verschuren \& F. Volckaert. 2001. Rapid, local adaptation of zooplankton behavior to changes in predation pressure in the absence of neutral genetic changes. Proc. Natl. Acad. Sci. USA, 98: 6256-6260.

Černý, M., \& J. Bytel. 1991. Density and size distribution of Daphnia pulicaria at different fish predation levels. Hydrobiologia, 225: 199-208.

Dirnberger, J.M. \& S.T. Threlkeld. 1986. Adverse effects of a reservoir flood on zooplankton abundance and dispersion. Freshwat. Biol., 16: 387-396.

Eckmann, R. 1998. Allocation of echo integrator output to small larval insect (Chaoborus sp.) and medium-sized (juvenile fish) targets. Fish. Res., 35: 107-113.

Folland, C.K., T.R. Karl \& M.J. Salinger. 2002. Observed climate variability and change. Weather, 57: 269-278.

Gido, K.B., W.J. Matthews \& W.C. Wolfinbarger. 2000. Long-term changes in a reservoir fish assemblage: stability in an unpredictable environment. Ecol. Appl., 10: 15171529.

Gliwicz, Z.M. 2003. Between hazard of starvation and risk of predation: The ecology of offshore animals. In: Kinne O. (Ed.) Excellence in ecology, Book 12. International Ecology Institute, Oldendorf/Luhe: 379 pp.

Gliwicz, Z.M. \& E. Siedlar. 1980. Food size limitation and algae interfering with food collection in Daphnia. Arch. Hydrobiol., 88: 155-177.

Gulati, R. \& W. DeMott. 1997. The role of food quality for zooplankton: remarks on the state-of-the-art, perspectives and priorities. Freshwat. Biol., 38: 753-768.

Guschina, I.A. \& J.L. Harwood. 2006. Mechanism of temperature adaptation in poikilotherms. FEBS Lett., 580: 5477-5483.

Hairston, N.G., W. Lampert, C.E. Cáceres, C.L. Holtmeier, L.J. Weider, U. Gaedke, J.M. Fischer, J.A. Fox \& D.M. Post. 1999. Rapid evolution revealed by dormant eggs. Nature, 401: 230

Hejzlar, J., J. Borovec, V. Perglová, E. Hanslík \& L. Nedvěd. 2008. Dating of sediments in the drinking water reservoir Rímov with caesium-137. In: Hanslík, E. (Ed.), Radionuclides and ionizing radiation in water management. Proceeding of a conference held in České Budějovice on May 5-7, 2008. Česká vědeckotechnická vodohospodářská společnost, Prague: 59-64 (in Czech).

Huisman, J., H.C.P. Matthijs \& P.M. Visser. 2005. Harmful cyanobacteria. Springer, Dordrecht: $251 \mathrm{pp}$.

Hülsmann, S. 2011. The combined effect of bottom-up and top-down factors on life history and reproduction of Daphnia in the field: is a strategic dilemma underlying population declines? J. Limnol., 70(2): 378-386.

Hülsmann, S. \& T. Mehner. 1997. Predation by underyearling perch (Perca fluviatilis) on a Daphnia galeata population in a short term enclosure experiment. Freshwat. Biol., 38: 209-219.

Hwang, J.S., R. Kumar \& C.S. Kuo. 2009. Impacts of predation by the copepod, Mesocyclops pehpeiensis, on life table demographics and population dynamics of four cladoceran species: a comparative laboratory study. Zool. Stud., 48: 738-752.
Jankowski, T. \& D. Straile. 2003. A comparison of egg-bank and long-term plankton dynamics of two Daphnia species, $D$. hyalina and D. galeata: Potentials and limits of reconstruction. Limnol. Oceanogr., 48: 1948-1955.

Johnk, K.D., D. Straile \& W. Ostendorp. 2004. Water level variability and trends in Lake Constance in the light of 1999 centennial flood. Limnologica, 34: 15-21.

Juračka, P.J., C. Laforsch \& A. Petrusek. 2011. Neckteeth formation in two species of the Daphnia curvirostris complex (Crustacea: Cladocera). J. Limnol., 70(2): 359-368.

Jürgens, K. \& G. Stolpe. 1995. Seasonal dynamics of crustacean zooplankton, heterotrophic nanoflagellates and bacteria in a shallow, eutrophic lake. Freshwat. Biol., 33: 27-38.

Jůza, T., J. Kubečka, M. Čech, M. Vašek, J. Peterka, V. Draštík, O. Jarolím, M. Prchalová, M. Kratochvíl \& J. Frouzová. 2006. Open water fish fry community in late summer. In: Proceedings of the 5th International Conference on Reservoir Limnology and Water Quality, Brno: 98-100.

Jůza, T., M. Vašek, J. Kubečka, J. Seda, J. Matěna, M. Prchalová, J. Peterka, M. Ríha, O. Jarolím, M. Tušer, M. Kratochvíl, M. Čech, J. Frouzová, E. Hohausová \& J. Žaloudík. 2009. Pelagic underyearling communities in a canyon-shaped reservoir in late summer. J. Limnol., 68: 304-314.

Kahl, U., S. Hülsmann, R.J. Radke \& J. Benndorf. 2008. The impact of water level fluctuations on the year class strength of roach: Implications for fish stock management. Limnologica, 38: 258-268.

Kirk, K.L. 1991. Suspended clay reduces Daphnia feeding rate. Freshwat. Biol., 25: 357-365.

Koppitz, H. 2004. Effects of flooding on the amino acid and carbohydrate patterns of Phragmites australis. Limnologica, 34: 37-47.

Kořínek, V. 1987. Carp ponds in central Europe. In: R.G. Michael (Ed.), Managed aquatic ecosystems. Elsevier, Amsterdam: 29-62.

Krueger, D.A. \& S.I. Dodson. 1981. Embryological induction and predation ecology in Daphnia pulex. Limnol. Oceanogr., 26: 219-223.

Laforsch, C., W. Ngwa, W. Grill \& R. Tollrian. 2004. An acoustic microscopy technique reveals hidden morphological defenses in Daphnia. Proc. Natl. Acad. Sci. USA, 101: 15911-15914.

Lampert, W. 1991. The dynamics of Daphnia magna in a shallow lake. Internat. Ver. Theor. Angew. Limnol., 24: 795-798.

Lampert, W. 2011. Daphnia: Development of a model organism in ecology and evolution. In: Kinne O. (Ed.), Excellence in ecology, Book 21. International Ecology Institute, Oldendorf/Luhe: $250 \mathrm{pp}$.

Loose, C.J. \& P. Dawidowicz. 1994. Trade-offs in diel vertical migration by zooplankton: The costs of predator avoidance. Ecology, 75: 2255-2263.

Lopez-Rodas, V., E. Maneiro, M.P. Lanzarot, N. Perdigones \& E. Costas. 2008. Mass wildlife mortality due to cyanobacteria in the Doñana National Park, Spain. Vet. Rec., 162: 317-318.

Lürling, M. 2003. Daphnia growth on microcystin-producing and microcystin-free Microcystis aeruginosa in different mixtures with the green alga Scenedesmus obliquus. Limnol. Oceanogr., 48: 2214-2220.

Macháček, J. 1991. Indirect effect of planktivorous fish on the growth and reproduction of Daphnia galeata. Hydrobiologia, 225: 193-197.

Martin-Creuzburg, D., E. von Elert \& K.H. Hoffmann. 2008. Nutritional constraints at the cyanobacteria-Daphnia magna interface: The role of sterols. Limnol. Oceanogr., 53: 456-468.

Martin-Creuzburg, D. \& E. von Elert. 2009. Ecological significance of sterols in aquatic food webs. In: M.T. Arts, 
M.T. Brett \& M.J. Kainz (Eds), Lipids in aquatic ecosystems. Springer, New York: pp. 43-64.

Matile, P. 1890. Die cladoceren der Umgegend von Moskau. Bull. Soc. imp. nat. Moscau, 1890(1): 1-67, pl. III-V.

Mearns, L.O., F. Giorgi, L. McDaniel \& C. Shields. 1995. Analysis of daily variability of precipitation in a nested regional climate model: comparison with observations and doubled $\mathrm{CO}_{2}$ results. Glob. Planet. Change, 10: 55-78.

Mills, E.L. \& J.L. Forney. 1983. Impact on Daphnia pulex of predation by young yellow perch in Oneida Lake, New York. Trans. Am. Fish. Soc., 112: 151-161.

Müller-Navarra, D. 1995. Evidence that a highly unsaturated fatty acid limits Daphnia growth in nature. Arch. Hydrobiol., 132: 297-307.

Murata, N. 1989. Low-temperature effects on cyanobacterial membranes. J. Bioenerg. Biomembr., 21: 61-75.

Neilan, B.A., M.L. Saker, J. Fastner, A. Torokne \& B.P. Burns. 2003. Phylogeography of the invasive cyanobacterium Cylindrospermopsis raciborskii. Mol. Ecol., 12: 133-140.

Ostendorp, W., M. Dienst \& K. Schmieder. 2003. Disturbance and rehabilitation of lakeside Phragmites reeds following an extreme flood in Lake Constance (Germany). Hydrobiologia, 506-509: 687-695.

Peters, R.H. \& R. de Bernardi (Eds). 1987. Daphnia. Mem. Ist. ital. Idrobiol., 45: $502 \mathrm{pp}$.

Petrusek, A., A. Hobæk, J.P. Nilssen, M. Skage, M. Černý, N. Brede \& K. Schwenk. 2008. A taxonomic reappraisal of the European Daphnia longispina complex (Crustacea, Cladocera, Anomopoda). Zool. Scr., 37: 507-519.

Pietrzak, B. 2011. Interclonal differences in age-specific performance in Daphnia magna. J. Limnol., 70(2): 345-352.

Reede, T. 1995. Life history shifts in response to different levels of fish kairomones in Daphnia. J. Plankton Res., 17: 1661-1667.

Reinikainen, M., J.A.O. Meriluoto, L. Spoof \& K. Harada. 2001. The toxicities of a polyunsaturated fatty acid and a microcystin to Daphnia. Eviron. Toxicol., 16: 444-448.

Rellstab, C. \& P. Spaak. 2007. Starving with full gut? Effect of suspended particles on fitness of Daphnia hyalina. Hydrobiologia, 594: 131-139.

Rellstab, C., V. Maurer, M. Zeh, H. R. Bürgi \& P. Spaak. 2007. Temporary collapse of the Daphnia population in turbid and ultra-oligotrophic Lake Brienz. Aquat. Sci., 69: 257-270.

Saker, M.L., J. Fastner, E. Dittmann, G. Christiansen \& V.M. Vasconcelos. 2005. Variation between strains of the cyanobacterium Microcystis aeruginosa isolated from Portuguese river. J. Appl. Microbiol., 99: 749-757.

Schmieder, K., M. Dienst \& W. Ostendorp. 2002. Effects of the extreme flood in 1999 on the spatial dynamics and stand structure of the reed belts in Lake Constance. Limnologica, 32: 131-146.

Seda, J. 1989. Main factors affecting spring development of herbivorous Cladocera in the Rímov Reservoir (Czechoslovakia). Arch. Hydrobiol. Beih. Ergebn. Limnol., 33: 619-630.
Seda, J. \& A. Duncan. 1994. Low fish predation pressure in London reservoirs: II. Consequences to zooplankton community structure. Hydrobiologia, 291: 179-191.

Seda, J. \& J. Kubečka. 1997. Long-term biomanipulation of Rímov Reservoir (Czech Republic). Hydrobiologia, 345: 95-108.

Stibor, H. 1992. Predator induced life-history shifts in a freshwater cladoceran. Oecologia, 92: 162-165.

Thielsch, A., N. Brede, A. Petrusek, L. De Meester \& K. Schwenk. 2009. Contribution of cyclic parthenogenesis and colonization history to population structure in Daphnia. Mol. Ecol., 18: 1616-1628.

Threlkeld, S.T. 1986. Life table responses and population dynamics of four cladoceran zooplankton during a reservoir flood. J. Plankton Res., 8: 639-647.

Tollrian, R. 1993. Neckteeth formation in Daphnia pulex as an example of continuous phenotypic plasticity - morphological effects of Chaoborus kairomone concentration and their quantification. J. Plankton Res., 15: 1309-1318.

Tollrian, R. \& F. Leese. 2010. Ecological genomics: steps towards unraveling the genetic basis of inducible defenses in Daphnia. BMC Biol., 8: 51.

Vaníčková, I., J. Seda, J. Macháček \& A. Petrusek. 2011. Effects of extreme floods on the Daphnia ephippial egg bank in a long narrow reservoir. J. Limnol., 70(2): 369-377.

Via-Ordorika, L., J. Fastner, R. Kurmayer, M. Hisbergues, E. Dittmann, J. Komárek, M. Erhard \& I. Chorus. 2004. Distribution of microcystin-producing and non-microcystinproducing Microcystis sp. in European freshwater bodies: detection of microcystins and microcystin genes in individual colonies. Syst. Appl. Microbiol., 27: 582-602.

von Elert, E., D. Martin-Creuzburg \& J.R. Le Coz. 2003. Absence of sterols constrains carbon transfer between cyanobacteria and a freshwater herbivore (D. galeata). Proc. $R$. Soc. Lond. B, 207: 1209-1214.

Vuorinen I., M. Ketola \& M. Walls. 1989. Defensive spine formation in Daphnia pulex Leydig and induction by Chaoborus crystallinus De Geer. Limnol. Oceanogr., 34: 245-248.

Wagner, A., S. Hülsmann, H. Dörner, M. Janssen, U. Kahl, T. Mehner \& J. Benndorf. 2004. Initiation of the midsummer decline of Daphnia as related to predation, non-consumptive mortality and recruitment: a balance. Arch. Hydrobiol., 160: 1-23.

Williams, G.C. 1957. Pleiotropy, natural selection, and the evolution of senescence. Evolution, 11: 398-411.

Wissel, B., N.D. Yan \& C.W. Ramcharan. 2003. Predation and refugia: implications for Chaoborus abundance and species composition. Freshwat. Biol., 48: 1421-1431.

Yan, N.D., R.W. Nero, W. Keller \& D.C. Lasenby. 1985. Are Chaoborus larvae more abundant in acidified than in nonacidified lakes in Central Canada? Holarct. Ecol., 8: 93-99.

Zsiros, O., Z. Várkonyi, A. Kovács, T. Farkas, Z. Gombos \& G. Garab. 2000. Induction of polyunsaturated fatty acid synthesis enhances tolerance of cyanobacterium, Cylindrospermopsis raciborskii, to low-temperature photoinhibition. Indian J. Biochem. Biophys., 37: 470-476. 